content and the chromatographic profile of the CEA activity of sputum from patients with cystic fibrosis.

\section{REFERENCES AND NOTES}

1. Boat, . F. Wiesman, U. N., and Pallavicini, J. C.: Purification and properties of the calcium-precipitable protein in submaxillary saliva of normal and cystic fibrosis subjects. Pediat. Res., 8: 531 (1974).

2. Bowman, B. H., Schmoyer, I., Barnett, D. R., Kurosky, A., and Hutchison, T. Cystic fibrosis-Biochemical characterization of the ciliary inhibitor. Amer. J. Genet., 25: 16A (1973.

3. Gold, R., Krupey, J., and Ansari, H.: Position of the carcinoembryonic antigen of the human digestive system in ultrastructure of tumor cell surface. J. Nat. Cancer Inst., 45: 219 (1970)

4. Gold, P., and Freedman, S. O.: Demonstration of tumor-specific antigens in human colonic carcinomata by immunological tolerance and absorption techniques. J. Exp. Med., I21: 439 (1965).

5. Hansen, J. J., Synder, J. J., Miller, E., Vandevoorde, J. P., Miller, O. H., Hines, L. R., and Burns, J. J.: Carcinoembryonic antigen (CEA) assay. A laboratory adjunct in the diagnosis and management of cancer. Human Pathol., 5: 139 (1974).

6. Lamblin, G., Degand, P., Roussel, P., Havez, R., Harteman, E., and Fillot, M.: Glycopeptides of bronchial fibrillar mucous in cystic fibrosis. Clin. Chem. Acta, 36: 329 (1972)

7. Laurence, D. J. R. Stevens, U., Bettelheim, R., Daray, D., Leese, C., Turberville, C., Alexander, P., Johns, E. W., and Neville, A. M.: Role of plasma, carcinoembryonic antigen in diagnosis of gastrointestinal, mannary and bronchial carcinoma. Brit. Med. J., 3: 605 (1972).

8. LoGerfo, P., Krupey, J., and Hansen, H. J.: Demonstration of an antigen common to several varieties of neoplasia. N. Engl. J. Med., 285: 138 (1971).

9. Martin, F., and Devant $\mathrm{J}$.: Carcinoembryonic antigen in normal human saliva. J. Nat. Can. Inst., 50: 1375 (1974).

10. Rogalsky, V. Y., and Konovich, E. A.: Localization of organ antigens in the human large intestine. Bull. Exp. Biol., 12: 64 (1971).

11. Rogalsky, V. Y.: Identity of carcino-embryonal antigen and antigen of mucousproducing cells. Lancet, $i: 1322$ (1973).

12. Rogalsky, V. Y.: Tumor-cell mucous protein and CEA. Lancet, ii: 729 (1974).

13. Roussel, E. Lamblin, G., Degan, P., and Havez, R.: Isolation of bronchial mucins secreated in cystic fibrosis. Clin. Chim. Acta, 36: 315 (1972)

14. Roussel, P., Lamblin, F., Degand, P., Walker-Masir, E., and Jeanlz, R. W. Heterogeneity of the carbohydrate chains of sulfated bronchial glycoprotein isolated from a patient suffering from cystic fibrosis. J. Biol. Chem., 250 2114 (1975)

15. Shwachman, H., and Kulczycki, L. L.: Long term study of one hundred five patients with cystic fibrosis-Studies made over a five to fourteen year period. Amer. J. Dis. Child., 96: 6 (1958).

16. Thomson, M. P., Kurpey, J., Freedman, S. O., and Gold, P.: The radioimmunoassay of circulating carcinoembryonic antigen of the human digestive system. Proc. Nat. Acad. Sci. U. S. A., 64: 161 (1969).

17. Wu, J. T., Herbst, J. J., and Bray, P. F.: Unpublished data; Manuscript in preparation

18. Wu, J. T., Madsen, A., and Bray, P. F.: Quantitative measurement and chromatography of human urinary carcinoembryonic antigen activity. J. Nat. Can. Inst., 53: 1589 (1974).

19. The authors wish to express their appreciation for the technical help of Mr. Ace Madsen and Miss Debbi Brown.

20. This research was supported by a grant from the National Cystic Fibrosis Research Foundation, Public Health Service Training Grants 2T 1-NS5503 and 5Ti-NS-5309 from the National Institute of Neurological Diseases and Stroke; Grant 73-0263 from Utah State Division of Health; small institutional gran from the American Cancer Society, University of Utah, and the Eleanor Roosevelt Cancer Research Foundation.

21. A portion of the results was presented at the 15th Annual Meeting for the Society of Pediatric Research, April 30, 1974 in Washington, D.C.

22. Requests for reprints should be addressed to: J. T. Wu, Ph.D., Division of Pediatric Neurology, University of Utah Medical Center, Salt Lake City, Utah 84132 (USA).

23. Accepted for publication November 17, 1975
Hemagglutination inhibition antibody influenza $\mathrm{A}$ virus intranasal local antibody recombinant virus serum antineuraminidase antibody vaccine, live

\title{
Temperature-sensitive Mutants of Influenza A Virus: Response of Children to the Influenza A/Hong Kong/68-ts-1[E] (H3N2) and Influenza A/Udorn/72-ts-1[E] (H3N2) Candidate Vaccine Viruses and Significance of Immunity to Neuraminidase Antigen
}

\author{
HYUN WHA KIM, JULITA O. ARROBIO, CARL D. BRANDT, ROBERT H. PARROTT, ${ }^{(29)}$ \\ BRIAN R. MURPHY, DOUGLAS D. RICHMAN, AND ROBERT M. CHANOCK \\ Research Foundation of Children's Hospital National Medical Center, Department of Child Health and \\ Development, George Washington University School of Medicine, Washington, D.C., and the Laboratory of \\ Infectious Diseases National Institute of Allergy and Infectious Diseases, National Institutes of Health,
} Bethesda, Maryland, USA

\section{Extract}

The influenza A/Hong Kong/1968-ts-1[E] (H3N2) candidate live virus vaccine strain, which had previously been shown to be safe and protective in seronegative adult volunteers, was administered intranasally to 21 children at a dose of $10^{5}$ TCID $_{50}$. One group contained 15 children (5-11 years of age) who lacked serum anti- body to the hemagglutinin $(\leq 1: 8)$, but possessed serum antibody to the neuraminidase antigen. The second group included six children $(24 / 12-31 \% 12$ years of age) who lacked serum antibody to both hemagglutinin and neuraminidase surface antigens of the influenza A virus. Twelve of the 15 children in the first group were infected, but only one child developed mild rhinitis; 6 of the 12 infected vaccinees shed virus for a short interval, while 11 of the group developed 
an immunologic response. In contrast, each of the six vaccinees who lacked serum antibody for both surface antigens of the virus shed a relatively larger quantity of virus over a longer interval than those in the first group, and each child developed an immunologic response. Four of the doubly seronegative vaccinees developed a febrile response during their infection and three had rhinitis. Two additional children who lacked serum antibody to both surface antigens of influenza virus were given the influenza A/Udorn/1972-ts-1[E] recombinant virus which had the same genetic temperature-sensitive (ts) lesions as the Hong Kong virus but possessed a more contemporary hemagglutinin. This recombinant virus infected both of the children and induced transient fever in one. None of the total of 23 vaccinees developed signs or symptoms of lower respiratory tract involvement. Although the Hong Kong and Udorn ts-1[E] recombinants possessed two discrete ts lesions, evidence of genetic instability was detected during infection of two of the eight young children who lacked immunity to both surface antigens of the virus. It seems likely that a complete assessment of the virulence of vaccine candidate influenza $A$ viruses can only be made in individuals who lack immunity to both surface antigens of the influenza $A$ virus.

\section{Speculation}

These findings suggest the following.

1. Antineuraminidase antibody (ANAB) to previously experienced influenza strains can modify clinical response to infection with attenuated influenza virus as well as natural infection.

2. The full expression of virulence of ts recombinants or any live influenza vaccine may be manifest only in individuals lacking both hemagglutination-inhibition (HI) antibody and ANAB.

3. Evaluation of the immune and clinical response to viruses such as the ts- $1[E]$ recombinant in young infants and children who lack both $H I$ antibody and $A N A B$ has value both because of their potential as vaccines and also as a model for an attenuated vaccine against the next pandemic influenza variant.

4. Standards for future ts or other live influenza vaccines must include genetic stability in individuals lacking $\mathrm{HI}$ antibody and ANAB and failure to induce a febrile response in such individuals.

Influenza infection and morbidity have seemed less important for infants and children than adults primarily because of the relatively greater frequency of other pediatric respiratory tract infections such as those caused by respiratory syncytial virus, parainfluenza viruses, and adenoviruses. In fact, up to $42 \%$ of infected infants and children may become ill during an influenza epidemic in an urban-suburban setting (7). Some epidemics have produced excess mortality in infants (3). Also, influenza infection is a major cause of infectious croup $(6,25)$. In our experience, influenza virus infection, particularly that due to the influenza $A$ $\mathrm{H} 2 \mathrm{~N} 2$ and $\mathrm{H} 3 \mathrm{~N} 2$ strains, was related etiologically to about $5 \%$ of hospitalized pediatric respiratory disease and $14 \%$ of croup illnesses seen between 1957 and 1974. The impact of influenza A virus was particularly apparent during epidemics; the virus was associated with $70 \%$ of croup illnesses, $29 \%$ of pneumonia illnesses, and $19 \%$ of all other hospitalized respiratory tract disease during the peak month of a composite of 11 consecutive influenza A virus outbreaks (14). In addition to experiencing significant morbidity from influenza A virus infection, preschool and school age children have been implicated as a major source of spread of infection in the community $(9,15)$.

Despite the significant impact of influenza A virus infection in children, routine immunization in normal infants with inactivated influenza vaccines has not been recommended. Inactivated influenza vaccines have produced an unacceptable level of systemic reaction $(10,11)$ and have been poorly antigenic in young children $(10,11)$. Even with the newer purified, inactivated vaccines there remain theoretical disadvantages such as the need for parenteral administration, requirement for a large amount of influenza antigen, and the relative inability of such vaccines to stimulate formation of antibody in the respiratory tract, particularly in the infant who is immunologically inexperienced with regard to influenzal antigens. If an attenuated vaccine administered into the respiratory tract were safe and effective, this development could provide the impetus for pediatricians and families to accept routine influenza immunization for the protection of children. Such immunization might tend to interrupt the spread of influenza infection throughout the community.

One potential live influenza $A$ virus vaccine strain is the influenza $\mathrm{A} / \mathrm{H}$ ong Kong/68-ts-1[E], an $\mathrm{H} 3 \mathrm{~N} 2$ recombinant virus which is greatly restricted in its replication at $38^{\circ}(17,18)$. This temperature-sensitive mutant and a further recombinant derived from it, the influenza $\mathrm{A} / \mathrm{Udorn} / 72$-ts-1[E] virus, were found to be safe, antigenic, stable genetically, noncommunicable, and protective in adults $(17,18)$. Thus, we undertook to study safety, antigenicity, and clinical response of these recombinant ts viruses in older children and then progressively in younger children.

Each of the adult vaccinees studied previously lacked serum H I antibody but possessed measurable levels of serum ANAB. Accordingly, we were particularly interested and concerned about the response of young children who might lack serum ANAB as well as serum HI antibody. Since neuraminidase immunity is effective in reducing the clinical response to infection with wild type influenza virus, it might also do so for the attenuated ts recombinant viruses $(2,5,8,18,19,23)$. Indeed the full expression of virulence of the ts recombinants or any live influenza virus vaccine may be manifest only in HI antibody- and ANABnegative individuals, i.e., doubly seronegative persons. Furthermore, it would be important to determine the immune response of doubly seronegative young children to viruses containing the ts-1[E] genetic lesions because of the potential usefulness of such recombinants for vaccination and as a model for the antigenicity of an attenuated vaccine directed against the next pandemic influenza variant which might possess new glycoprotein hemagglutinin and neuraminidase surface antigens.

To date we have administered the 1968 Hong Kong ts recombinant to 21 children, $2-11$ years of age, who had a serum $\mathrm{HI}$ antibody titer of 1:8 or less. Some of the vaccinees also lacked serum ANAB. We also administered a 1972 Udorn ts recombinant containing the same ts-l[E] genetic lesions as the Hong Kong recombinant to two young children who lacked serum $\mathrm{HI}$ antibody and $A N A B$.

\section{MATERIALS AND METHODS}

\section{VIRUS}

The production and safety testing of the influenza A/Hong Kong/68-ts- 1 [E] (H3N2) virus employed in the present study have been described previously $(17,22)$. Briefly, the Hong Kong/68-ts$1[E]$ virus was a recombinant virus resulting from a mating of the influenza $A / G r e a t$ Lakes/65-ts-1 (H2N2) and the wild type influenza A/Hong Kong/68 (H3N2) viruses. The recombinant possessed the Hong Kong hemagglutinin (H3) and the temperature-sensitivity property of the 1965-ts-1 parent, i.e., restriction of replication at $38^{\circ}$. The Hong Kong/68-ts-1[E] virus was grown in the allantoic cavity of hen's eggs free of leucosis virus (27) and titered $10^{6.0} \mathrm{TCID}_{50} / \mathrm{ml}$ in rhesus monkey kidney cell culture. The virus was administered by "nose drops" in a dose of $10^{5}$ $\mathrm{TCID}_{50} /$ child.

The Udorn/72-ts-1[E] recombinant was prepared by mating influenza $\mathrm{A} /$ Hong Kong/68-ts-1[E] virus and an influenza A/ Udorn/1972 (H3N2) wild type virus (antigenically similar to influenza $\mathrm{A} /$ England/42/72 virus) (21). The Udorn/72-ts-1[E] (clone 24 ) recombinant was administered intranasally in a dose of $10^{4.5} / \mathrm{TCID}_{50}$.

\section{EVALUATION OF CANDIDATE VACCINES IN CHILDREN}

The recombinant vaccines were evaluated in children who had a serum HI antibody titer of 1:8 or less. Two children were admitted at a time to the Clinical Research Center of Children's Hospital, Washington, D.C., and were observed closely for 7-12 days after 
virus administration. They shared a hospital room and special precautions were taken to prevent extraneous infection. In particular, parents and hospital personnel entering the room were required to wear masks. For each child, written informed consent was obtained from a parent or guardian after the aims and procedures of the study had been explained. Older children were evaluated first, then young children, and finally younger children without serum ANAB.

The children were examined at least twice daily and various specimens obtained as follows: nasal and throat swabs daily; anal swabs twice weekly; nasal secretions before vaccine administration and $1,2,3,5,10$, and 20 weeks thereafter; serum samples before administration and 3, 5, 10, and 20 weeks thereafter.

Antibody studies have been performed to date only on nasal secretions obtained before vaccination and at 3,5, and 20 weeks thereafter and on serum specimens before vaccination and at 3 or 5 weeks and 20 weeks for $\mathrm{HI}$ antibody and 3 weeks for ANAB.

\section{VIRUS ISOLATION AND TEST FOR GENETIC STABILITY}

A combined nose and throat swab specimen was inoculated into primary rhesus monkey kidney (RMK) roller tube cultures which were incubated at $33^{\circ}$ and tested for hemadsorption with $0.4 \%$ guinea pig erythrocytes as described previously (24). All positive nasal-throat swab specimens were subsequently titered in parallel in a single test on RMK tube cultures and the titers expressed as $\mathrm{TCID}_{50} \mathrm{per} / \mathrm{ml}$ of swab fluid. In addition, daily specimens from children who received the $\mathrm{U} d$ dorn $\mathrm{ts}-1[\mathrm{E}]$ recombinant were titrated for virus content without prior freezing.

The ts recombinant vaccine viruses did not produce plaques in monolayer cultures of $\mathrm{RMK}$ at $39^{\circ}$, which was considered a restrictive temperature. To determine the genetic stability of the Hong Kong/ts-1[E] and Udorn/ts-1[E] viruses after replication in children, each of the isolates recovered in RMK culture was tested for its ability to form plaques on RMK monolayer cultures at $33^{\circ}$ and $39^{\circ}(17)$. Those isolates which produced plaques at $39^{\circ}$ were considered to contain genetically altered (ts + ) virus.

\section{HI, NEUTRALIZING, AND ANAB DETERMINATIONS}

For the Hong Kong/68-ts-1[E] studies, the HI antibody titer was determined by standard microtiter assay using 4 antigen units of a recombinant virus containing the hemagglutinin of the influenza $\mathrm{A} / \mathrm{Aichi} / 68$ (H3N2) virus and an irrelevant neuraminidase, $\mathrm{N}$ equi $_{1}$. For the Udorn/72-ts-1[E] studies, a recombinant virus containing the hemagglutinin of the influenza $\mathrm{A} /$ England/42/72 (H3N2) virus and the $\mathrm{N}$ equi, neuraminidase was used. The influenza A/Hong Kong/68 and influenza A/Aichi/68 viruses were antigenically equivalent strains; similarly, influenza $\mathrm{A} /$ England/42/72 and $\mathrm{A} / \mathrm{Udorn} / 307 / 72$ viruses were equivalent. All serum samples were tested in parallel in a single test.

Since it has recently been reported that the standard neutralization test performed in roller tube cultures measures both $\mathrm{HI}$ antibody and ANAB (13), the technique employed in the present study utilized the $\mathrm{H} 3$ (Aichi) $\mathrm{N}$ equi ${ }_{1}$ or the $\mathrm{H} 3$ (England/72) $\mathrm{N}$ equi $_{1}$ recombinant virus as antigen and therefore measured only antihemagglutinin antibody. The seed viruses, provided by Dr. Marion Coleman, were adapted to growth in RMK culture by serial passage at limit dilution to achieve a test antigen suspension that contained approximately $10^{6}$ infectious units for each hemagglutinin unit. The test was performed in RMK tube cultures using 16-32 antigen units as described previously and titers were adjusted to $10 \mathrm{mg} / 100 \mathrm{ml}$ immunoglobulin A (24). All nasal wash specimens were assayed in a single test.

The serum ANAB titer was determined by neuraminidase-inhibition assay using the $\mathrm{H}$ equi ${ }_{1} \mathrm{~N}_{2}$ (Aichi/68) or the $\mathrm{H}$ equi $\mathrm{N}_{2}$ (England/72) recombinant virus antigen as described previously (1). These viruses were also provided by Dr. Coleman. Virus titers were expressed as that dilution of serum which caused a $50 \%$ inhibition of enzyme activity. A rise in titer of $1.5 \log _{2}$ was considered significant in our assay system.

\section{RESULTS}

\section{CLINICAL RESPONSE}

The Hong Kong/68-ts-1[E] recombinant virus was administered to 21 children, 2-11 years of age (Table 1). Eighteen were infected as determined by any or all of the following criteria: virus recovery, serum HI antibody rise, serum ANAB rise, or nasal secretion antibody rise. Each of the six youngest vaccinees who lacked serum $A N A B$ became infected.

The children were remarkably free of lower respiratory tract symptoms during infection. Cough, chills, myalgia, sweating, sneezing, or nasal obstruction were not observed. Mild, transient, nonpurulent rhinorrhea of 2 or 3 days duration was observed in 3 of 6 children who lacked serum ANAB and 1 of 12 who had serum $A N A B$. Four of the six vaccinees who lacked pre-existing serum ANAB developed a transient temperature elevation to $38.2^{\circ}$ or greater during ‘virus shedding; the highest temperature was $39^{\circ}$. In contrast none of the children with ANAB became febrile. The vaccinees were free of systemic reactions except for the four children who had transient fever.

Although there were no placebo controls in these studies to monitor the possibility that other viruses or bacteria might be responsible for the fever and rhinitis, there was careful viral and bacterial monitoring. No other agents were found to explain thèse symptoms.

\section{VIRUS SHEDDING BY VACCINEES}

Virus shedding was detected in 12 of the 21 vaccinees. The six children who lacked serum $A N A B$ prior to administration of vaccine shed more virus for a longer duration than those who possessed serum ANAB (Table 1). There was no relationship

Table 1. Response of seronegative children (serum hemagglutination-inhibiting antibody $\leq 1: 8$ ) to intranasal administration of $10^{5: 3}$ $T C I D_{50}$ of influenza A/Hong Kong/68-ts-I[E] vaccine virus (H3N2) ${ }^{1}$

\begin{tabular}{|c|c|c|c|c|c|c|c|c|c|}
\hline \multirow[b]{2}{*}{$\begin{array}{c}\text { Vaccinees } \\
\text { with } \\
\text { pre-existing } \\
\text { serum } \\
\text { ANAB }\end{array}$} & \multirow[b]{2}{*}{ Age, yr } & \multirow[b]{2}{*}{$\begin{array}{l}\text { No. in } \\
\text { group }\end{array}$} & \multirow[b]{2}{*}{$\begin{array}{c}\text { No. } \\
\text { infected }^{2}\end{array}$} & \multirow[b]{2}{*}{$\begin{array}{c}\text { No. who } \\
\text { shed } \\
\text { virus }\end{array}$} & \multirow[b]{2}{*}{$\begin{array}{c}\text { Average } \\
\text { no. of } \\
\text { days } \\
\text { virus } \\
\text { shed }^{3}\end{array}$} & \multirow[b]{2}{*}{$\begin{array}{l}\text { Geometric } \\
\text { mean }^{3} \text { peak } \\
\text { titer of } \\
\text { virus shed } \\
\left(\log _{10}\right)\end{array}$} & \multicolumn{3}{|c|}{ Illness } \\
\hline & & & & & & & $\begin{array}{c}\text { No. who } \\
\text { had } \\
\text { rhinitis }\end{array}$ & $\begin{array}{c}\text { No. who had } \\
\text { fever (range } \\
\text { of peak } \\
\text { temp, }{ }^{\circ} \mathrm{C} \text { ) }\end{array}$ & $\begin{array}{c}\text { Total } \\
\text { with } \\
\text { illness }\end{array}$ \\
\hline $\begin{array}{l}\text { No } \\
\text { Yes }\end{array}$ & $\begin{array}{l}24 / 12-310 / 12 \\
56 / 12-11\end{array}$ & $\begin{array}{r}6 \\
15\end{array}$ & $\begin{array}{r}6 \\
12\end{array}$ & $\begin{array}{l}6 \\
6\end{array}$ & $\left.\begin{array}{l}4.5 \\
1.2\end{array}\right]{ }^{4}$ & $\left.\begin{array}{l}2.1 \\
0.7\end{array}\right]$, & $\begin{array}{l}3 \\
1\end{array}$ & $\begin{array}{l}4(38.2-39.0) \\
0\end{array}$ & $\left.\begin{array}{l}6 \\
1\end{array}\right] 5$ \\
\hline
\end{tabular}

ANAB: antineuraminidase antibody.

${ }^{2}$ Recovery of virus and/or a fourfold or greater rise in serum and/or nasal secretion antibody.

${ }^{3}$ Calculated only for infected vaccinees.

${ }^{4}$ Statistically significant difference between values at the ends of bracket (Student's $t$-test, $P 0.01$ ).

${ }^{5}$ Statistically significant difference between values at the ends of bracket (Fischer exact test, $P 0.005$ ). 
Table 2. Response of seronegative children (serum hemagglutination-inhibition antibody $(H I) \leq 1: 8)$ to intranasal administration of $10^{5}$ $T C I D_{50}$ of influenza A/Hong Kong/68-ts-l[E] vaccine virus $(H 3 N 2)^{1}$

\begin{tabular}{|c|c|c|c|c|c|c|c|c|c|c|c|c|c|}
\hline \multirow{3}{*}{$\begin{array}{l}\text { Vaccinees } \\
\text { with } \\
\text { pre-existing } \\
\text { serum } \\
\text { ANAB }\end{array}$} & \multirow{3}{*}{$\begin{array}{l}\text { No. in } \\
\text { group }\end{array}$} & \multicolumn{4}{|c|}{ Serum HI antibody ${ }^{2}$} & \multicolumn{3}{|c|}{ Serum ANAB ${ }^{3}$} & \multicolumn{5}{|c|}{ Nasal wash neutralizing antibody } \\
\hline & & \multicolumn{3}{|c|}{$\begin{array}{l}\text { Reciprocal (geometric } \\
\text { mean } \log _{2} \text { ) antibody } \\
\text { titer at indicated week } \\
\text { after virus } \\
\text { administration }\end{array}$} & \multirow{2}{*}{$\begin{array}{l}\text { No. with } \\
4 \text {-fold } \\
\text { or } \\
\text { greater } \\
\text { rise }\end{array}$} & \multicolumn{2}{|c|}{$\begin{array}{c}\text { Reciprocal } \\
\text { (geometric mean } \\
\log _{2} \text { ) antibody titer } \\
\text { at indicated week } \\
\text { after virus } \\
\text { administration }\end{array}$} & \multirow{2}{*}{$\begin{array}{l}\text { No. with } \\
1.5 \log _{2} \\
\text { or } \\
\text { greater } \\
\text { rise }\end{array}$} & \multicolumn{4}{|c|}{$\begin{array}{l}\text { Reciprocal (geometric } \\
\text { mean } \log _{2} \text { ) antibody } \\
\text { titer at indicated week } \\
\text { after virus } \\
\text { administration }\end{array}$} & \multirow{2}{*}{$\begin{array}{l}\text { No. with } \\
\text { 4-fold } \\
\text { or } \\
\text { greater } \\
\text { rise }\end{array}$} \\
\hline & & 0 & $3-5$ & 20 & & 0 & 3 & & 0 & 3 & 5 & 20 & \\
\hline No & 6 & 1.1 & 5.0 & 3.8 & 6 & $\leq 1$ & 2.9 & 5 & 0.49 & 3.2 & 1.2 & 1.4 & 3 \\
\hline Yes & 15 & 2.0 & 3.6 & 3.4 & 10 & 8.8 & 10.0 & 5 & 1.1 & 1.8 & 2.7 & 1.2 & 7 \\
\hline
\end{tabular}

${ }^{1}$ ANAB: antineuraminidase antibody.

${ }^{2} \mathrm{HI}$ antibody titers determined using 4 antigen units of $\mathrm{H} 3$ (Hong Kong) $\mathrm{N}$ equi ${ }_{1}$ virus.

${ }^{3}$ ANAB Titers determined using $\mathrm{H}$ equi ${ }_{1} \mathrm{~N} 2$ (Hong Kong) virus as antigen.

${ }^{4}$ Neutralizing antibody titers determined using 16 antigen units of $\mathrm{H} 3$ (Hong Kong) $\mathrm{N}$ equi ${ }_{1}$ virus.

between virus shedding and the level of serum $A N A B$ in those with pre-existing ANAB. With one exception, the Hong Kong/68-ts1[E] virus maintained its ts phenotype during replication in children. Of 42 isolates obtained, 41 maintained ts phenotype. One isolate obtained from a vaccinee on day 7 produced plaques at $39^{\circ}$ which contained virus with the wild type phenotype (ts + ), but such ts + virus:made up only a very small proportion of the total virus populationin the isolate (a ratio of $100 \mathrm{ts}: 1$ ts + ). Significantly, no ts + virus was detected in the isolates obtained on day 8 and day 9 from this vaccinee. No ts + virus was detected by direct plaque assay of the original day 7 swab specimen from this vaccinee.

\section{HI ANTIBODY, ANAB, AND NASAL NEUTRALIZING ANTIBODY RESPONSE}

Sixteen of the 21 vaccinees had a fourfold or greater rise in serum $\mathrm{HI}$ antibody and this antibody persisted for at least 20 weeks postvaccination ( $P=0.01$, using Student's $t$-test on 0 - and 20 -week serum specimens) (Table 2 ). Ten of the 21 vaccinees developed a significant rise in ANAB titer. Five of the six children who lacked serum ANAB $(<1: 2)$ at the time of virus administration had a significant rise in $A N A B$ titer.

Ten of 21 vaccinees had a fourfold or greater rise in nasal wash neutralizing antibody that persisted for at least 5 weeks after vaccination. The difference in antibody titers between the 0 - and 3 -week and 0 - and 5-week serum specimens was significant $(P<$ 0.05 , Student's $t$-test). However, in contrast to the serum $\mathrm{Hl}$ antibody pattern, there was not a significant elevation in nasal wash antibody level at 20 weeks.

\section{RESPONSE TO UDORN/1972 ts-1[E] RECOMBINANT}

The two children (age $29 / 12$ and 3 years) who received $10^{4.5}$ $\mathrm{TCID}_{50}$ of the Udorn/72-ts-1[E] virus lacked serum HI antibody and $\mathrm{ANAB}$ at the time of virus administration. They shed virus from the 2 nd to the 10 th day after inoculation with peak titers of $10^{3.7} \mathrm{TCID}_{50} / \mathrm{ml}$ of swab fluid. Revertant virus (ts + ) was detected in an isolate of one vaccinee on day 5 but was not detected on previous or subsequent days. This virus represented a minority component $(<1 \mathrm{ts}+: 1,000 \mathrm{ts})$ in the original swab specimen. Both children had serum $\mathrm{HI}$ antibody and serum ANAB responses comparable with those seen in children receiving the Hong Kong/68-ts-1[E] virus. One of the vaccinees had a febrile response (maxium fever $39^{\circ}$ ) which lasted 2 days and both had watery rhinorrhea for 7-10 days, but neither vaccinee exhibited any signs or symptoms of lower respiratory tract disease. Thus it appeared that the Udorn recombinant behaved similarly to the Hong Kong-ts- $1[E]$ recombinant in young children who had not undergone influenza A virus infection previously.

\section{DISCUSSION}

This study indicated that children 5 years and older who lacked serum $\mathrm{HI}$ antibody, but who had prior immunologic experience with influenza $A$ virus as indicated by possession of serum ANAB, behaved similarly to immunologically comparable adults after intranasal administration of the influenza A/Hong Kong/68-ts1[E] candidate vaccine virus. The children's response was characterized by: $(l)$ the occurrence in a minority of vaccinees of mild signs and symptoms affecting the upper respiratory tract; (2) virus shedding of short duration, limited to the first 5 days after vaccine administration; (3) low level of virus replication in the upper respiratory tract; and (4) stimulation of serum $\mathrm{HI}$ antibody, serum $A N A B$, and nasal wash neutralizing antibody. A single dose of $10^{5}-10^{6} \mathrm{TCID}_{50}$ of the ts- 1 [E] vaccine infected approximately $90 \%$ of adults or children who had a serum HI antibody titer of $\leq 1: 8$ $(17,18)$. These results suggest that the Hong Kong/68-ts-1[E] virus has an acceptable level of attenuationaand is antigenic for individuals 5 years of age and older. Importantly, such children did not manifest an exaggerated response to the vaccine virus.

In contrast to the children who possessed serum ANAB at the time of virus administration, those children who lacked both serum $A N A B$ and HI antibody had a more extensive clinical and virologic response. Four of the six doubly seronegative children had a temperature elevation $\left(38.2-39^{\circ}\right)$ and this group as a whole shed more virus for a longer period than children who had pre-existing serum ANAB. This suggests that antineuraminidase immunity naturally acquired from previous infection provided some protection against illness produced by the candidate vaccine viruses. This suggestion is offered with the reservations that there was an age difference in the two groups and that the effectsof antihemagglutinin immunity below the level of detection of the $\mathrm{HI}$ test could not be assessed. However, it seems likely that a complete assessment of the virulence of vaccine candidate influenza $A$ viruses can be made only in individuals who lack immunity to both surface antigens of the influenza A virus. Only when doubly seronegative children were evaluated did it become apparent that the ts-1[E] recombinant viruses retained some virulence. Nonetheless, we were encouraged that the level of virulence of the Hong Kong/68 and Udorn/72 ts-1[E] viruses was low in such children, i.e., no signs of lower respiratory tract involvement were evident. Systemic febrile responses similar to those seen in the doubly seronegative children would be anticipated if a ts-1[E] recombinant virus with the appropriate new surface antigens were administered at the time of the next influenza pandemicto individuals of any age who lacked immunity to both hemagglutinin and neuraminidase antigens of the new virus.

Importantly, the live attenuated ts viruses were antigenic in all children who lacked serum $\mathrm{HI}$ antibody and ANAB. The HI 
antibody persisted for at least 5 months after virus administration. Seven of the eight doubly seronegative children developed ANAB. This was somewhat unexpected in light of previous studies which suggested that an ANAB response to primary infection with influenza $A$ virus $(\mathrm{H} 2 \mathrm{~N} 2)$ was unusual $(4,12)$. This apparent difference most likely reflects the increased sensitivity of the neuraminidase-inhibition assay used in the present study (1).

The present study suggested that the Hong Kong/68-ts-1[E] virus is attenuated and is immunogenic in both immunologically experienced and inexperienced children. Similar results in the two children who received the more contemporary Udorn ts-1[E] recombinant suggested that findings with the Hong Kong recombinant can be extrapolated to other recombinants prepared in the same manner and containing the ts-1[E] temperature-sensitive lesions.

The ts-1[E] recombinants were shown recently to contain two discrete ts lesions which were located on different RNA pieces of the segmented genome $(20,21)$. Despite the existence of ts lesions on two separate RNA segments of the viral genome, the recombinants exhibited evidence of genetic instability during infection of 2 of 8 young doubly seronegative children in the present study and 4 of 18 similar children in another study (26). In contrast, the recombinants were stable genetically when given to a considerably larger number of adults and older children who lacked detectable antibody to $\mathrm{HA}$ antigen, but possessed measurable neuraminidase immunity $(17,18)$. It appeared that emergence of ts + revertants occurred only in the absence of immunity to both hemagglutinin and neuraminidase antigens; presumably this favored an unrestricted type of infection. These revertants represented only a very small proportion of the virus produced during infection of doubly seronegative children and the emergence of revertant virus under these conditions was not associated with lower respiratory tract disease.

In view of the occurrence of reversion and low grade fever, studies with the ts-1[E] recombinants in children have been discontinued. Although the Hong Kong ts-1[E] virus did not prove to be the ideal donor of ts lesions for a live influenza vaccine it did prove helpful in establishing new standards to be required for future ts influenza vaccine viruses-namely genetic stability in doubly seronegative individuals and failure to induce a febrile response in such persons. Other ts mutants which contain two independent ts lesions in regions of the viral genome which do not code for hemagglutinin and neuraminidase antigens are currently under study and several appear to be more stable genetically than the $t s-1[E]$ virus. These viruses will be evaluated in adult volunteers shortly.

\section{SUMMARY}

One of two slightly different influenza $A / t s-1[E]$ recombinant candidate live vaccines was given intranasally to each of 23 young children. Twelve of 15 children who had no serum $\mathrm{HI}$ antibody but who did have serum ANAB at the time of administration became infected and 1 had mild rhinitis. All eight who lacked both types of antibody became infected and they shed virus in higher titer and for longer than the former group; five had rhinorrhea and five had mild fever. These findings suggest that serum ANAB plays a part in modulating influenza virus infection and that the full expression of virulence of these or other attenuated influenza vaccines may be manifest only in individuals lacking both $\mathrm{HI}$ antibody and ANAB. These particular candidate vaccine strains appear to be attenuated for older children (who have some prior experience with influenza A as demonstrated by serum ANAB), but the occurrence of fever in over half who had no prior experience indicates that they would not be acceptable for a vaccine in wide-spread use.

\section{REFERENCES AND NOTES}

1. Aymard-Henry, M., Coleman, M. T., Dowdle, W. R., Laver, W. G., Schild, G. C., and Webster, R. G.: Influenzavirus neuraminidase and neuraminidase inhibition test procedures. Bull. World Health Org., 48 : 199 (1973).

2. Couch, R. B., Kasel, J. A., Gerin, J. L., Schulman, J. L., and Kilbourne, E. D. Induction of partial immunity to influenza using a neuraminidase-specific vaccine. J. Infect. Dis., 129: 411 (1974).

3. Dauer, C. C., and Serfling, R. E.: Mortality from influenza. Amer. Rev. Resp. Dis. Suppl. 83: 15 (1961)

4. Davenport, F. M., Minuse, E., and Hennessy, A. V.: Antibody response to influenza virus enzyme in man: Antineuraminidase antibody levels measured with the recombinant strain X-15. Arch. Envir. Health, 21: 307 (1970).

5. Dowdle, W. R., Mostow, S. R., Coleman, M. T., Kaye, H. S., and Schoenbaum, S. C.: Inactivated influenza vaccines. 2. Laboratory indicies of protection. Postgrad. Med. J., 44: 159 (1973).

6. Forbes, J. A.: Severe effects of influenza virus infection. Med. J. Australia, 2: 75 (1958).

7. Foy, H. M., Cooney, M. K., and McMahan, R.: A/Hong Kong influenza immunity three years after immunization. J. Amer. Med. Ass., 226: 758 (1973)

8. Greenberg, S. B., Couch, R. B., and Kasel, J. A.: An outbreak of an influenza type A varient in a closed population: The effect of homologous and heterologous antibody on infection and illness. Amer. J. Epidemiol., 100: 209 (1974).

9. Hall, C. E., Cooney, M. K., and Fox, J. P.: The Seattle Virus Watch. IV. Comparative epidemiologic observations of infections with influenza A and B virus, 1965-1969, in families with young children. Amer. J. Epidemiol., 98: 365 (1973).

10. Hennessy, A. V., and Davenport, F. M.: Vaccination of infants against influenza with polyvalent influenza hemagglutinin. J. Amer. Med. Ass., 200:896 (1967).

11. Hennessy, A. V., and Davenport, F. M.: Studies on vaccination of infants against influenza with influenza hemagglutinin. Proc. Soc. Exp. Biol. Med., 146: 200 (1974).

12. Hennessy, A. V., Minuse, E., and Davenport, F. M.: Anti-neuraminidase antibody response of man to influenza virus neuraminidase N2: Results obtained with an improved hemagglutination inhibition technique and enzyme inhibition test. J. Immunol., 109: 213 (1972).

13. Kasel, J. A., Couch, R. B., Gerin, J. L., and Schulman, J. L.: Effect of influenza anti-neuraminidase antibody on virus neutralization. Infect. Immunol., 8: 130 (1973).

14. Kim, W. H., Arrobio, J. O., Brandt, C. D., Chanock, R. M., Murphy, B. R., and Parrot, R. H.: Unpublished data.

15. Monto, A. S., Davenport, F. M.. Napier, J. A., and Francis, T., Jr.: Effect of vaccination of a school-age population upon the course of an $\mathrm{A} 2 / \mathrm{Hong} \mathrm{Kong}$ influenza epidemic. Bull. World Health Org., 41: 537 (1969).

16. Monto, A. S., and Kendal, A. P.: Effect of neuraminidase antibody on Hong Kong influenza. Lancet $i: 623$ (1973).

17. Murphy, B. R., Chathub, E. G., Nusinoff, S. R., and Chanock, R. M.: Temperature-sensitive mutants of influenza virus. II. Attenuation of ts recombinants for man. J. Infect. Dis., I26: 170 (1972)

18. Murphy, B. R., Chalhub, E. G., Nusinoff, S. R., Kasel, J., and Chanock, R. M.: Temperature-sensitive mutants of influenza virus. 1II. Further characterization of the ts-1(E) influenza A recombinant $(\mathrm{H} 3 \mathrm{~N} 2)$ virus in man. J. Infect. Dis. 128: 479 (1973).

19. Murphy, B. R., Kasel, J. A., and Chanock, R. M.: Association of serum antineuraminidase antibody with resistance to influenza in man. N. Engl. J. Med., 286: 1239 (1972)

20. Murphy, B. R., Spring, S. B., Richman, D. D., Tierney, E. L., Kasel, J., and Chanock, R. M.: Temperature sensitive mutants of influenza virus. VII Transfer of the ts-1(E) lesions to a wild type influenza A virus with the HONI surface antigens. Virology (In press).

21. Richman, D. D., Murphy, B. R., Spring, S. B., Coleman, M. T., and Chanock, R M.: Temperature sensitive mutants of influenza virus. IX. Genetic and biological characterization of ts-1(E) lesions when transferred to a 1972 (H3N2) influenza A virus. Virology (In press).

22. Spring, S. B., Nusinoff, S. R., Mills, J. V., Richman, D. D., Tierney, E. L. Murphy, B. R., and Chanock, R. M.: Temperature-sensitive mutants of influenza virus. VI. Transfer of ts lesions from the Asian subtype of influenza A virus (H2N2) to the Hong Kong subtype (H3N2). Virology (In press).

23. Tyrrell, D. A. J., Buckland, R. A., Schild, G. C., Freestone, D. S., Chinn, S., and Slepushkin, A. N.: Nasal and circulating antibody responses to influenza vaccination and their importance in resistance to infection. Postgrad. Med. J. 49: 200 (1973).

24. Van Kirk, J. E., Mills, J. V., and Chanock, R. M.: Evaluation of low temperature grown influenza A2/Hong Kong virus in volunteers. Proc. Soc. Exp. Biol. Med., 136: 34 (1971)

25. Vargosko, A. J., Chanock, R. M., Huebner, R. J., Luckey, A. H., Kim, H. W., Cumming, C., and Parrott, R. H.: Association of type 2 hemadsorption (parainfluenza 1) virus and Asian influenza $A$ virus with infectious croup. $N$. Eng. J. Med., 261: 1 (1959).

26. Wright, P. F., Shinozaki, T., Thompson, J. M., and Karzon, D. T.: Live influenza A (H3N2) ts-1(E) vaccine in children. Pediat. Res., 9: 347 (1975).

27. SPAFAS, Inc., Storrs, Conn.

28. This research was supported in part by the National Institute of Allergy and Infectious Diseases Contract No. Al 12091.

29. Requests for reprints should be addressed to: R. H. Parrott, M.D., Director, Children's Hospital of the District of Columbia, 2125 13th St. N. W., Washington, D.C. 20009 (USA).

30. Accepted for publication November 17, 1975. 